\title{
The effect of freezing and drying Cornus mas L. from phenols, flavonoids, anthocyanins, and total content of ascorbic acid and antioxidant activity in two methods
}

\author{
Marzieh Piryaei ${ }^{1^{*}}$, \\ Marzieh Babashpour Asl ${ }^{2}$, \\ Mir Mahdi Abolghasemi ${ }^{1}$ \\ ${ }^{1}$ Department of Chemistry, \\ Faculty of Science, \\ University of Maragheh, \\ Maragheh 5519700634, Iran \\ ${ }^{2}$ Department of Horticulture, \\ College of Agriculture, \\ Maragheh Branch, \\ Islamic Azad University, \\ Maragheh 5519747591, Iran
}

\begin{abstract}
Flavonoids, anthocyanins, antioxidant capability, total content of phenolic and ascorbic acid of Cornus mas of frozen and dried for polar and non-polar subfraction were evaluated in this work. Antioxidant activities of the samples were determined by three testing systems, namely, DPPH, $\beta$-carotene/linoleic acid, and reducing power assay. In the DPPH system, the highest radical scavenging activity was seen in the polar subfraction of the methanol extract in frozen fruits $\left(\mathrm{IC}_{50}=25.15 \pm 6.5 \mu \mathrm{g} \mathrm{mL} \mathrm{L}^{-1}\right)$. Comparison of two methods of extraction, maceration and the ultrasonic method, showed that the results of maceration are better than those of the ultrasonic method. These advantages are visible in extracting the flavonoids, anthocyanins, antioxidant capability, and the total content of phenolic and ascorbic acid.
\end{abstract}

Keywords: total phenols, flavonoids, anthocyanins, ascorbic acid, antioxidant, Cornus mas L.

\section{INTRODUCTION}

The Cornelian cherry (Cornus mas L.) is a wild plant that grows in Asia and Europe. Its mature scarlet fruit has sour taste. The fruits of the Cornelian cherry contain significant amounts of anthocyanins. It is known that anthocyanins have antioxidant and anti-inflammatory effects. They have been also used for the medical treatment of gastrointestinal disorder and diarrhoea in people. There are several reports about its use in traditional medicine and as a food preservative. It is

“Corresponding author. Email: m.piriyaei@gmail.com also reported to have anti-bacterial, anti-histamine, anti-allergic, anti-microbial, and anti-malarial activities. The Cornus fruits feature among the major constituents of several antidiabetic herbal preparations in Asian countries (Tural, Koca, 2008). Today, an important field of research is the control of the 'redox' status by consuming foods with high antioxidant properties. Natural antioxidants in the diet increase resistance to oxidative stress and may have a substantial impact on human health (Gholivand et al., 2014).

Several methods have been developed to measure the free radical scavenging capacity (RSC) regardless of the individual compounds that 
contribute to wards the total capacity of a plant in scavenging free radicals. Typically, these methods are based on the inhibition of the accumulation of oxidized products, since the generation of free radical species is inhibited by the addition of antioxidants and this gives rise to a reduction of the end point by scavenging free radicals. A reliable method to determine the RSC involves the measurement of the disappearance of free radicals, such as the 2,2-azino-bis (3-ethylbenzenthiazoline-6-sulphonic) acid radical (ABTS $\bullet$ ), the 2,2-diphenyl-1-picrylhydrazyl radical $\left(\mathrm{DPPH}^{\circ}\right)$ or other coloured radicals, with a spectrophotometer (Miller, Rice-Evans, 1997; Sanchez-Moreno et al., 1998; Choi et al., 2002). This present study was intended to study the total content of phenolics, total flavonoids, anthocyanins, ascorbic acid, and antioxidant activity of Cornus mas in frozen and dried fruits in the polar and non-polar subfractions with two methods of extraction.

\section{MATERIALS AND METHODS}

\section{Chemicals}

Linoleic acid, 2,6-di-tert-butyl-4-methylphenol (butylated hydroxytoluene, BHT), 2,2-diphenyl-1-picrylhydrazyl (DPPH, 95\%), gallic acid, oxalic acid, ascorbic acid (AA), catechin, PVPP (polyvinyl polypyrrolidone), cyanidin -3-glucoside, and $\beta$-carotene were procured from Sigma-Aldrich Chemie (Steinheim, Germany). Analytical grade methanol, ethanol, and HPLC grade chloroform, standard Folin-Ciocalteu's phenol reagent, anhydrous sodium sulphate, ferric chloride, sodium carbonate, potassium ferricy-anide, phosphate buffer solution (PBS), and Tween 40 were obtained from Merck (Darmstadt, Germany). The fruits of Cornus mas were gathered in the summer of 2016. Fruits were stored both frozen and dried.

\section{Maceration}

Four hundred (400) grams of frozen and $400 \mathrm{~g}$ of dried fruits were put in methanol at $45^{\circ} \mathrm{C}$ (frozen fruits) and $50^{\circ} \mathrm{C}$ (dried fruits) for 45 and 60 hours, respectively. The extracts were filtered and concentrated under vacuum. The extracts were filtered and concentrated under vacuum at $50^{\circ} \mathrm{C}$ by using a rotary evaporator. These extracts were suspended in water and extracted with chloroform $(3 \times 500 \mathrm{ml})$. They were stored in darkness at $4^{\circ} \mathrm{C}$ until used within a maximum period of one week. The extractions were separated with water (polar) and chloroform (non-polar).

\section{Ultrasonic Extraction}

The sample was weighed accurately (400 g) and mixed with $1000 \mathrm{~mL}$ of the solvent in a reagent bottle. The bottle was then closed and placed in the ultrasonic bath with temperature maintained at $45^{\circ} \mathrm{C}$ for $15 \mathrm{~min}$ for frozen and at $50^{\circ} \mathrm{C}$ for $20 \mathrm{~min}$ for dried fruits using ultrasonicator (42 kHz, heat power $250 \mathrm{~W}, \mathrm{KQ}-500 \mathrm{DE}, \mathrm{MTH}$, China). The mixture was then filtered through Whatman filter paper No. 4 and the filtrate was evaporated under reduced pressure at $50^{\circ} \mathrm{C}$. These extracts were suspended in water and extracted with chloroform $(3 \times 500 \mathrm{ml})$. The extracts were stored in darkness at $4^{\circ} \mathrm{C}$ until used within a maximum period of one week. The extractions were separated with water (polar) and chloroform (non-polar).

\section{Antioxidant properties}

\section{1,1-Diphenyl-2-picrylhydrazyl radical (DPPH)} scavenging activity

The free radical-scavenging activities of the extract were measured by using 2,2-diphenyl1-picryl-hydrazyl (DPPH) as described by Sharififar et al. (2007), with some modification. Three millilitres of various concentrations of the extract was added to $1 \mathrm{ml}$ of a $0.5 \mathrm{mM}$ methanol solution of DPPH. The mixture was vigorously shaken and left to stand at room temperature for $60 \mathrm{~min}$ in the dark. Then the absorbance was measured at $517 \mathrm{~nm}$ against a blank. Inhibition of free radical, DPPH, in per cent (I\%) was calculated according to the formula:

$$
\mathrm{I} \%=\left(\left(A_{b}-A_{S}\right) / A_{b}\right) \times 100
$$

where $A_{b}$ is the absorbance of the control reaction (containing all reagents except the test compound), and $A_{s}$ is the absorbance of the test compound. The sample concentration providing $50 \%$ inhibition $\left(\mathrm{IC}_{50}\right)$ was calculated from 
the graph of inhibition percentage against sample concentration. Tests were carried out in triplicate. Ascorbic acid (AA) was used as positive control.

\section{$\boldsymbol{\beta}$-Carotene linoleic acid assay}

The antioxidant activity was evaluated according to the method described by Miller (1971), with some modifications. Briefly, $1.5 \mathrm{~mL}$ of $\beta$-carotene solution ( $1 \mathrm{mg} / \mathrm{mL}$ in chloroform), $3 \mathrm{~mL}$ of linoleic acid solution (10 mg/mL in chloroform), and $1.0 \mathrm{~mL}$ of Tween 40 solution $(300 \mathrm{mg} / \mathrm{mL}$ in chloroform) were pipetted into a $250 \mathrm{~mL}$ flask. The chloroform was removed by a rotary vacuum evaporator, $150 \mathrm{~mL}$ deionized water was added to the residue, and the mixture was shaken to form an emulsion. $350 \mu$ of the test sample in methanol $(2 \mathrm{mg} / \mathrm{ml})$ was mixed with $2.5 \mathrm{~mL}$ of this reagent, and the emulsion system was incubated for up to $24 \mathrm{~h}$ at room temperature. The same procedure was repeated with the synthetic antioxidant, BHT as positive control, and a blank containing only $350 \mu \mathrm{l}$ of methanol. After this incubation period, absorbances of the mixtures were measured at $490 \mathrm{~nm}$. Antioxidative capacities of the extract were compared with those of BHT and blank.

\section{Reducing power}

The reducing power of the extract was determined according to the method of Sfahlan et al. (2009), with some modifications. Different concentrations of methanol extract (polar and non-polar) of the plant in methanol $(1.0 \mathrm{ml})$ were mixed with $2.5 \mathrm{ml}$ of phosphate buffer $(200 \mathrm{mM}, \mathrm{pH} 6.6)$ and $2.5 \mathrm{ml}$ of $1 \%$ potassium ferricyanide. The mixture was incubated at $50^{\circ} \mathrm{C}$ for $20 \mathrm{~min}$. A portion $(2.5 \mathrm{ml})$ of trichloroacetic acid (10\%) was added to the mixture to stop the reaction, which was then centrifuged at $3000 \mathrm{~g}$ for $10 \mathrm{~min}$. The upper layer of the solution $(2.5 \mathrm{ml})$ was mixed with distilled water $(2.5 \mathrm{ml})$ and $\mathrm{FeCl}_{3}(0.5 \mathrm{ml}$, $0.1 \%)$, and the absorbance was measured at $700 \mathrm{~nm}$ : higher absorbance indicates higher reducing power. Ascorbic acid was used as positive control.

\section{Determination of total phenolic contents}

Total phenolic content of the extracts was determined using the Folin-Ciocalteu reagent according to the method of Singleton and Rossi (1965) of using gallic acid as standard, with some modifications. The extract solution $(0.1 \mathrm{ml})$ containing $1000 \mu \mathrm{g}$ of the extract was mixed with $46 \mathrm{ml}$ of distilled water in a volumetric flask, $1 \mathrm{ml}$ of Folin-Ciocalteu reagent was added, and the flask was thoroughly shaken. The mixture was allowed to react for $3 \mathrm{~min}$ after which $3 \mathrm{ml}$ aqueous solution of $2 \% \mathrm{Na}_{2} \mathrm{CO}_{3}$ was added. At the end of incubation of $2 \mathrm{~h}$ at room temperature, absorbance of each mixture was measured at $760 \mathrm{~nm}$. The same procedure was also applied to the standard solutions of gallic acid, and a standard curve was obtained. Total phenol content was expressed as $\mu \mathrm{g}$ gallic acid equivalents per mg of the extract. All tests were carried out in triplicate, and gallic acid equivalent values were reported as $\mathrm{X} \pm \mathrm{SD}$ of triplicates.

\section{Determination of total flavonoids}

A modified protocol of the one described by Kim et al. (2003) was employed. A $0.1 \mathrm{ml}$ aliquot of methanolic extract, appropriately diluted, was mixed with $0.4 \mathrm{ml}$ distilled water in a $1.5 \mathrm{ml}$ micro-centrifuge tube, $0.03 \mathrm{ml}$ of $5 \%$ $\mathrm{NaNO}_{2}$ was added, and the mixture was allowed to react for $5 \mathrm{~min}$. Following this, $0.03 \mathrm{ml}$ of $10 \% \mathrm{AlCl}_{3}$ was added and the mixture stood for further $5 \mathrm{~min}$. Finally, the reaction mixture was treated with $0.2 \mathrm{ml}$ of $1 \mathrm{M} \mathrm{Na}_{2} \mathrm{CO}_{3}$ and $0.24 \mathrm{ml}$ distilled water, and the absorbance at $510 \mathrm{~nm}$ was obtained against a blank prepared similarly, by replacing the extract with distilled water. Total flavonoid content was calculated from a calibration curve using catechin as standard and expressed as mg catechin equivalents (CTE) per $100 \mathrm{~g}$ plant (Dourtoglou et al., 2006).

\section{Ascorbic acid content}

Ascorbic acid of the extracts was determined using ascorbic acid as standard, with some modifications. The samples ( $1 \mathrm{~g})$ and $4 \mathrm{ml}$ oxalic acid (1\%) were mixed, homogenised for $1 \mathrm{~min}$, and filtered. PVPP (polyvinylpolypyrrolidone) 
(100 g) was added to $2.5 \mathrm{ml}$ of the filtered sample to remove phenols, and 2-3 drops of $\mathrm{H}_{2} \mathrm{SO}_{4}$ (25\%) were added to reduce the $\mathrm{pH}$ to below 1 . Absorbance of the mixture was determined at $254 \mathrm{~nm}$. Results were expressed as $\mu \mathrm{g}$ ascorbic acid (AA) $100 \mathrm{mg}^{-1}$ sample weight (sw) (Pantelidis et al., 2007).

\section{Anthocyanins}

Total anthocyanin content was measured with the $\mathrm{pH}$ differential absorbance method as described by Cheng and Breen (1991). Briefly, absorbance of the extracts were measured at 510 and $700 \mathrm{~nm}$ in buffers at $\mathrm{pH} 1.0$ (hydrochloric acid-potassium chloride, $0.2 \mathrm{M}$ ) and 4.5 (acetate acid-sodium acetate, $1 \mathrm{M}$ ). Anthocyanin content was calculated using a molar extinction coefficient of 29,600 (cyanidin-3-glucoside) and absorbance of

$$
\mathrm{A}=\left[\left(\mathrm{A}_{510}-\mathrm{A}_{700}\right)_{\mathrm{pH} 1.0}-\left(\mathrm{A}_{510}-\mathrm{A}_{700}\right)_{\mathrm{pH} 4.5}\right]
$$

Results were expressed as $\mu \mathrm{g}$ cyanidin3-glucoside equivalents $100 \mathrm{mg}^{-1}$ sw (Cheng and Breen, 1991).

\section{RESULTS AND DISCUSSION}

\section{Free radical-scavenging activity}

The effect of antioxidant on DPPH radical scavenging was thought to be due to their hydrogen donating ability or radical-scavenging activity. When a solution of DPPH is mixed

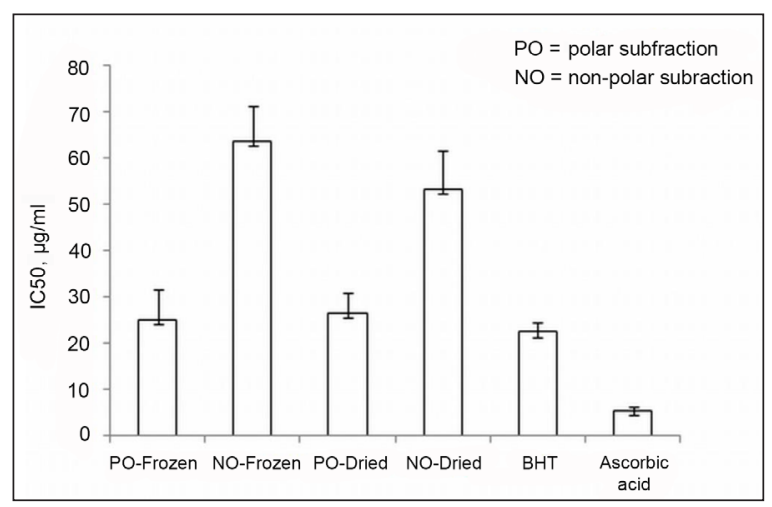

Fig. 1. DPPH radical-scavenging activities of Cornus mas in polar (PO) and non-polar (NO) subfractions of frozen and dried fruits with maceration extraction with that of a substance that can donate a hydrogen atom, then this gives rise to the reduced form 1,1-diphenyl-2-picryl hydrazine (non-radical) with the loss of this violet colour (Molyneux, 2004). DPPH scavenging activity is usually presented by the $\mathrm{IC}_{50}$ value, defined as the concentration of the antioxidant needed to scavenge $50 \%$ of DPPH present in the test solution. A lower $\mathrm{IC}_{50}$ value reflects a better DPPH radical-scavenging activity (Molyneux, 2004; Gholivand et al., 2010).

In this study, the effect of two extraction methods - ultrasound and maceration - for the efficient extraction of antioxidative compounds from Cornus mas in the case of frozen and dried was investigated. Methanol was chosen as the solvent because alcohols are most widely used in antioxidant extraction work. During extraction, it was seen that maximum extraction yield was achieved with macerate extraction.

The polar subfraction in frozen fruits of methanol extract provided the highest radicalscavenging activity with the lowest $\mathrm{IC}_{50}$ value of $25.15 \pm 6.5 \mu \mathrm{g} / \mathrm{ml}$ for maceration method. In addition, DPPH scavenging abilities of the methanol extracts were lower than that of synthetic antioxidant BHT. Ascorbic acid and BHT were used as standards. Figs. 1 and 2 show a comparison between polar and non-polar subfraction in frozen and dried fruits with maceration and ultrasonic extraction.

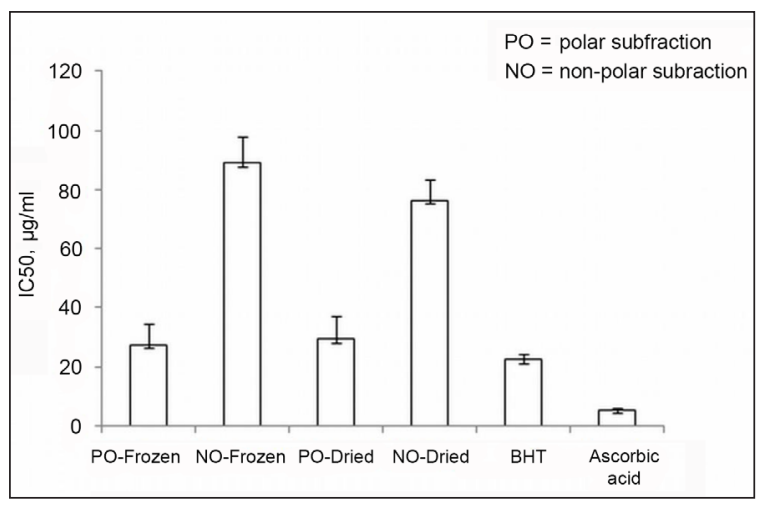

Fig. 2. DPPH radical-scavenging activities of Cornus mas in polar (PO) and non-polar (NO) subfractions of frozen and dried fruits with ultrasonic extraction 
The antioxidant activities of the plant extract were also evaluated by the spectrophotometric $\beta$-carotene bleaching test. In a $\beta$-carotene/ linoleic acid model system, $\beta$-carotene undergoes rapid discoloration in the absence of an antioxidant. $\beta$-carotene bleaching method is based on the loss of the yellow colour of $\beta$-carotene due to its reaction with radicals formed by linoleic acid oxidation in an emulsion. The rate of $\beta$-carotene bleaching can be slowed down in the presence of antioxidants (Kulisic et al., 2004). The relative antioxidative activities (RAAs) of the extracts were calculated from the equation, $\mathrm{RAA}=\mathrm{A}$ sample/A BHT, where $\mathrm{A}$ BHT is the absorbance of the control (BHT) and A sample is the absorbance of the extract. The calculated RAAs of the extract are given in Figs. 3

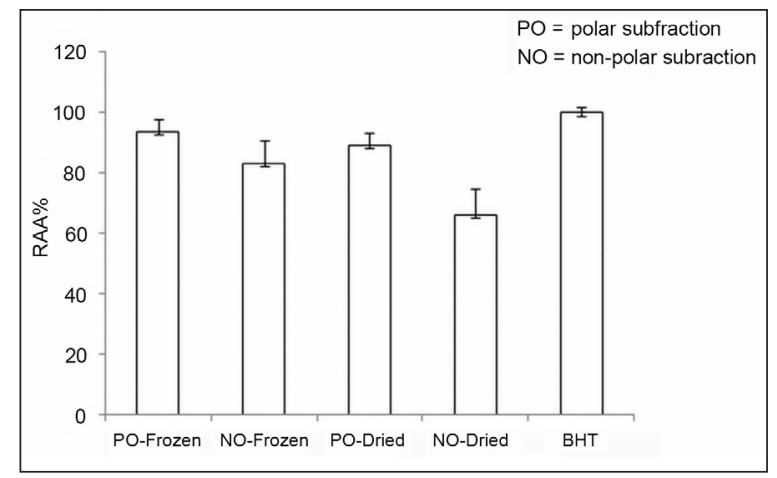

Fig. 3. Relative antioxidative activities (RAAs) of Cornus mas in the polar (PO) and non-polar (NO) subfractions of frozen and dried fruits with maceration extraction

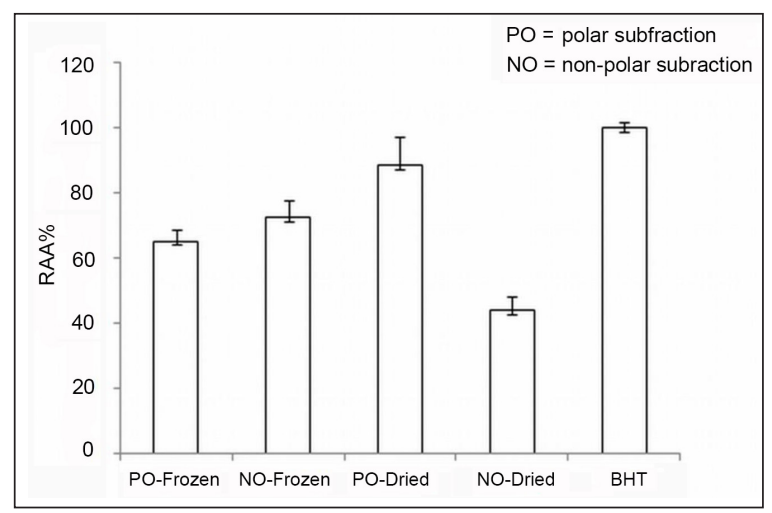

Fig. 4. Relative antioxidative activities (RAAs) of Cornus mas in the polar (PO) and non-polar (NO) subfractions of frozen and dried fruits with ultrasonic extraction and 4 . In both assays, the polar subfraction in frozen fruits of methanol extract for maceration method showed better antioxidative capacity than the other subfraction.

Different studies have indicated that the electron donation capacity reflects the reducing power of bioactive compounds in associated with antioxidant activity. Antioxidants can be explained as reducers, and inactivation of oxidants by reducers can be described as a redox reaction in which one reaction species is reduced at the expense of the oxidation of the other. $\mathrm{Fe}^{3+}$ reduction is often used as an indicator of electron donating activity, which is an important mechanism of phenolic antioxidant action (Yildirim et al., 2001; Gholivand et al., 2010). In the reducing power assay, the presence of antioxidants in the sample would result in the reduction of $\mathrm{Fe}^{3+}-\mathrm{Fe}^{2+}$ by donating an electron. The amount of $\mathrm{Fe}^{2+}$ complex can be then be monitored by measuring the formation of Perl's Prussian blue $\left(\mathrm{Fe}^{4}\left[-\mathrm{Fe}(\mathrm{CN})_{6}\right]^{3}\right)$ at $700 \mathrm{~nm}$. Increasing absorbance at $700 \mathrm{~nm}$ indicates an increase in the reductive ability (Gholivand et al., 2010). Figs. 5 and 6 show the reducing power of the methanol extract of Cornus mas as a function of their concentrations. It was found that the reducing power of the extract increased with the increase of their concentrations.

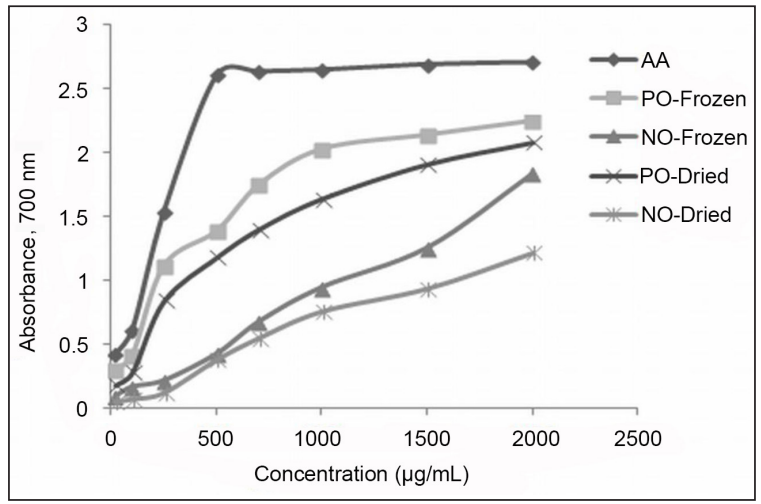

Fig. 5. Reducing power of different concentrations of methanol extract polar and non-polar subfractions of frozen and dried fruits with maceration of Cornus mas compared to ascorbic acid, (spectrophotometric detection of the $\mathrm{Fe}^{+3}-\mathrm{Fe}^{+2}$ transformations). Polar (PO) and non-polar (NO) subfraction extract; AA: ascorbic acid 


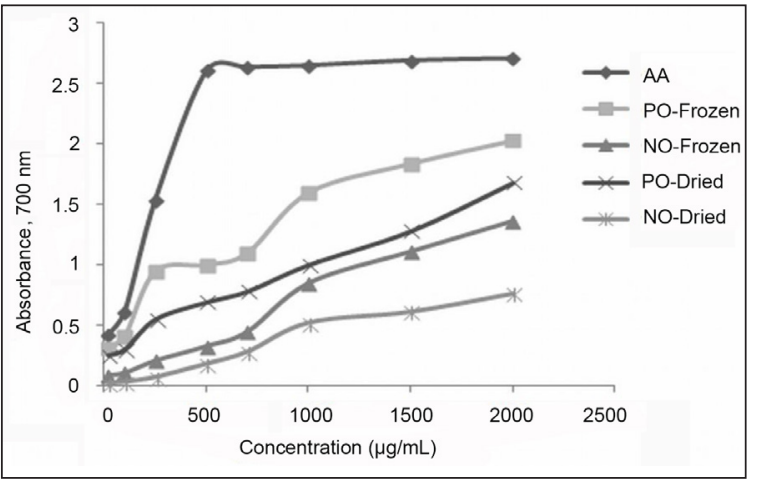

Fig. 6. Reducing power of different concentrations of methanol extract polar and non-polar subfractions of frozen and dried fruits with ultrasonic extraction of Cornus mas compared to ascorbic acid, (spectrophotometric detection of the $\mathrm{Fe}^{+3}-\mathrm{Fe}^{+2}$ transformations). Polar (PO) and non-polar (NO) subfraction extract; AA: ascorbic acid

\section{Determination of total phenolic compounds}

The amounts of total phenolics in the extract of frozen and dried fruits were determined spectrometrically according to the Folin-Ciocalteu procedure and calculated as gallic acid equivalents. Gallic acid is a water-soluble polyhydroxyphenolic compound that can be found in various natural plants. The standard curve equation was

$y($ absorbance $)=0.0003 \times$ gallic acid $(\mu \mathrm{g})$ +0.00534 .

The absorbance value was inserted in the above equation and the total amount of phenolic compound was calculated. The amounts of total phenols found in the plant methanol extract are shown in Figs. 7 and 8.

The results indicated that the polar subfraction in frozen form in methanol extract with maceration method has higher total phenolic compounds than other subfractions. In addition, according to these results, there is a relationship between total phenol contents and antioxidant activity. Phenolic compounds, biologically active components, are the main agents that can donate hydrogen to free radicals and thus break the chain reaction of lipid oxidation at the first initiation step. This high potential of phenolic compounds to scavenge radicals may be ex-

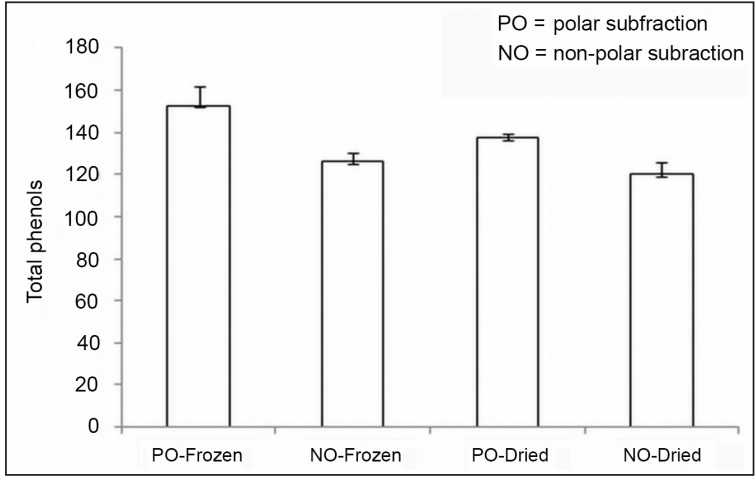

Fig. 7. The total phenols of Cornus mas in the polar (PO) and non-polar (NO) subfractions of the frozen and dried fruits with ultrasonic extraction

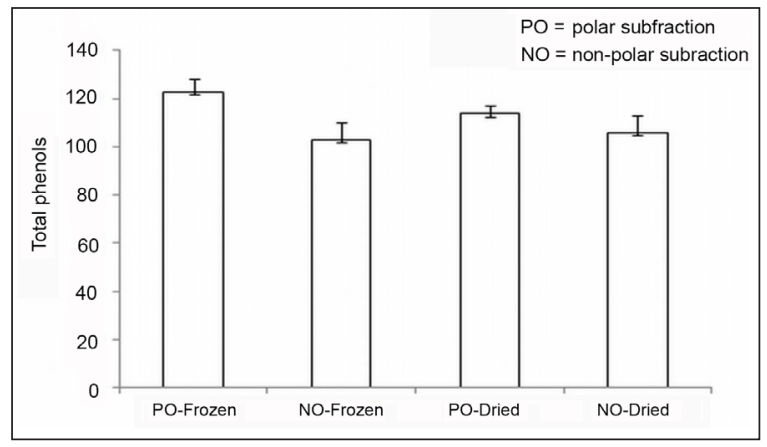

Fig. 8. The total phenols of Cornus mas in the polar (PO) and non-polar (NO) subfractions of the frozen and dried fruits with ultrasonic extraction

plained by their phenolic hydroxyl groups (Sun et al., 2002).

\section{Flavonoid}

The standard curve equation for the determination of flavonoids with catechin is

$y$ (absorbance $)=0.004 \times$ catechin $(\mu \mathrm{g})$ +0.0495 .

The amounts of total flavonoids for frozen and dried fruits of Cornus mas with two extraction methods are shown in Table 1.

\section{Table 1. The amounts of total flavonoids}

\begin{tabular}{ccc}
\hline Stage & Extractin & Flavonoids \\
\hline Frozen & Maceration & $76.32 \pm 7.4$ \\
\hline & Ultrasonic & $58.65 \pm 8.1$ \\
\hline Dried & Maceration & $61.59 \pm 2.6$ \\
\hline & Ultrasonic & $19.74 \pm 5.3$ \\
\hline
\end{tabular}




\section{Anthocyanins}

Significant differences in anthocyanin content were recorded, since these pigments are responsible for the red and blue colour. The polar subfraction in frozen fruits contained the highest anthocyanin content expressed as cyanidin-3-glucoside. The results are shown in Tables 2 and 3.

\section{Ascorbic acid}

Significant differences in ascorbic acid content among the different subfractions are recorded in Tables 2 and 3. The polar subfraction in frozen fruits had the highest content of ascorbic acid (4.89 $\left.\mathrm{mg} 100 \mathrm{~g}^{-1} \mathrm{sw}\right)$.

Table 2. The amounts of anthocyanin and ascorbic acid with maceration method

\begin{tabular}{c|c|c|c}
\hline Stage & Fraction & $\begin{array}{c}\text { Ascorbic } \\
\text { acid }\end{array}$ & $\begin{array}{c}\text { Anthocy- } \\
\text { anin }\end{array}$ \\
\hline Frozen & $\begin{array}{c}\text { Polar-sub- } \\
\text { fraction }\end{array}$ & $4.89 \pm 1.05$ & $21.52 \pm 3.76$ \\
\hline & $\begin{array}{c}\text { Nonpolar- } \\
\text { subfraction }\end{array}$ & $3.22 \pm 0.73$ & $13.75 \pm 4.25$ \\
Dried & $\begin{array}{c}\text { Polar-sub- } \\
\text { fraction }\end{array}$ & $4.43 \pm 0.59$ & $14.93 \pm 2.85$ \\
\hline \multicolumn{4}{c}{ Nonpolar- } \\
subfraction & $2.21 \pm 0.32$ & $10.36 \pm 2.61$ \\
\hline
\end{tabular}

Table 3. The amounts of anthocyanin and ascorbic acid with ultrasonic method

\begin{tabular}{|c|c|c|c|}
\hline Stage & Fraction & $\begin{array}{l}\text { Ascorbic } \\
\text { acid }\end{array}$ & $\begin{array}{c}\text { Anthocya- } \\
\text { nin }\end{array}$ \\
\hline \multirow[t]{2}{*}{ Frozen } & $\begin{array}{l}\text { Polar-sub- } \\
\text { fraction }\end{array}$ & $2.15 \pm 0.78$ & $12.95 \pm 5.42$ \\
\hline & $\begin{array}{l}\text { Nonpolar- } \\
\text { subfraction }\end{array}$ & $1.62 \pm 0.18$ & $4.70 \pm 1.07$ \\
\hline \multirow[t]{2}{*}{ Dried } & $\begin{array}{l}\text { Polar-sub- } \\
\text { fraction }\end{array}$ & $1.36 \pm 0.08$ & $14.93 \pm 2.85$ \\
\hline & $\begin{array}{l}\text { Nonpolar- } \\
\text { subfraction }\end{array}$ & $0.69 \pm 0.07$ & $7.61 \pm 1.38$ \\
\hline
\end{tabular}

\section{CONCLUSIONS}

According to the results of this study, the methanol extracts of Cornus mas may be suggested as a strong potential source of a natural antioxidant. The methanol extract in different subfractions were found to be effective antioxidants in different in vitro assays including $\beta$-carotene bleaching, DPPH radical scavenging and reducing power which can be proposed as a natural additive in food and pharmaceutical industries. There was a good correlation between total phenol content and antioxidant capacity of the extracts.

Received 11 October 2017 Accepted 12 June 2018

\section{References}

1. Cheng GW, Breen PJ. Activity of phenylalanine ammonialyase (PAL) and concentrations of anthocyanins and phenolics in developing strawberry fruit. J Am Soc Hortic Sci. 1991; 116(5): 865-9.

2. Choi CW, Kim SC, Hwang SS, Choi BK, Ahn HJ, Lee MY, Park SH, Kim SK. Antioxidant activity and free radical scavenging capacit y bet ween Korean medicinal plants and flavonoids by assay-guided comparison. Plant Sci. 2002; 163(6): 1161-8.

3. Dourtoglou VG, Mamalos A, Makris DP. Storage of olives (Olea europaea) under $\mathrm{CO}_{2}$ atmosphere: Effect on anthocyanins, phenolics, sensory attributes and in vitro antioxidant properties. Food Chem. 2006; 99(2): 342-9.

4. Gholivand MB, Piryaei M, Maassoumi SM. Antioxidant activity of Ziziphora tenuoir methanolic extracts and comparison of the essential oil in two stages of growth. Chin J Nat Med. 2014; 12(7): 505-11.

5. Gholivand MB, Rahimi-Nasrabadi M, Batooli H, Abdolrasoul H. Ebrahimabadi. Chemical composition and antioxidant activities of the essential oil and methanol extracts 
of Psammogeton canescens. Food Chem Toxicol. 2010; 48(1): 24-8.

6. Kim DO, Chun OK, Kim YJ, Moon HY, Lee CY. Quantification of polyphenolics and their antioxidant capacity in fresh plums. J Agric Food Chem. 2003; 51(22): 6509-15.

7. Kulisic T, Radonic A, Katalinic V, Milos M. Use of different methods for testing antioxidative activity of oregano essential oil. Food Chem. 2004; 85(4): 633-40.

8. Miller HE. A simplified method for the evaluation of antioxidants. J Am Oil Chem Soc. 1971; 48(2): 91-7.

9. Miller NJ, Rice-Evans CA. Factors influencing the antioxidant activity determined by the $\mathrm{ABTS}^{+}$radical cation assay. Free Rad Res. 1997; 26(3): 195-9.

10. Molyneux P. The use of the stable free radical diphenylpicrylhydrazyl (DPPH) for estimating antioxidant activity. Songklanakarin J Sci Technol. 2004; 26: 211-9.

11. Pantelidis GE, Vasilakakis M, Manganaris GA, Diamantidis Gr. Antioxidant capacity, phenol, anthocyanin, and ascorbic acid contents in raspberries, blackberries, red currants, gooseberries and Cornelian cherries. Food Chem. 2007; 102(3): 777-83.

12. Sanchez-Moreno C, Larrauri JA, Saura-Calixto F. A procedure to measure the ant iradical efficiency of polyphenols. J Sci Food Agric. 1998; 76(2): 270-6.

13. Singleton VL, Rossi JA. Colorimetry of total phenolics with phosphomolybdic-phosphotungstic acid reagents. Am J Enol Vitic. 1965; 16: 144-58.

14. Sharififar F, Moshafi MH, Mansouri SH, Khodashenas M, Khoshnoodi M. In vitro evaluation of antibacterial and antioxidant activities of the essential oil and methanol extract of endemic Zataria multiflora Boiss. Food Control. 2007; 18(7): 800-5.

15. Sfahlan AJ, Mahmoodzadeh A, Hasanzadeh A, Heidari R, Jamei R. Antioxidants and antiradicals in almond hull and shell (Amygdalus communis L.) as a function of genotype. Food Chem. 2009; 115: 529-533.

16. Sun J, Chu YF, Wu X, Liu RH. Antioxidant and antiproliferative activities of common fruits. J Agric Food Chem. 2002; 50(25): 449-54.

17. Tural S, Koca I. Physico-chemical and antioxidant properties of cornelian cherry fruits (Cornus mas L.) grown in Turkey. Sci Hortic. 2008; 116(4): 362-6.

18. Yildirim A, Mavi A, Kara AA. Determination of antioxidant and antimicrobial activities of Rumex crispus L. extracts. J Agric Food Chem. 2001; 49(8): 4083-9.

\section{Marzieh Piryaei, Marzieh Babashpour Asl, Mir Mahdi Abolghasemi}

\section{ŠALDYMO IR DŽIOVINIMO POVEIKIS CORNUS MAS L. BENDRAM FENOLIŲ, FLAVONOIDŲ, ANTOCIANINŲ, ASKORBO RÜGŠTIES KIEKIUI IR ANTIOKSIDACINIAM AKTYVUMUI}

\section{Santrauka}

Norint gauti šaldytą ir džiovintą polinę bei nepolinę subfrakcijas, šiame darbe buvo įvertintos flavonoidų, antocianinų ir antioksidantų savybès, bendras fenolio ir askorbo rūgšties kiekis geltonžiedeje seduloje (Cornus mas). Mèginių antioksidacinis aktyvumas buvo nustatytas naudojant tris bandymo sistemas - DPPH, $\beta$-karotino / linolo rūgšti ir redukcinį galios testą. DPPH sistemoje didžiausias radikalų šalinimo aktyvumas užfiksuotas šaldytų vaisių metanolio ekstrakto polinejje subfrakcijoje $\left(\mathrm{IC} 50=25,15 \pm 6,5 \mu \mathrm{g} \mathrm{ml}^{-1}\right)$. Palyginus du ekstrahavimo būdus - maceraciją ir ultragarsą - paaiškejo, kad maceracijos rezultatai yra geresni nei ultragarso. Šis pranašumas stebimas ekstrahuojant flavonoidus, antocianinus - užtikrinamas antioksidantų, bendras fenolio ir askorbo rūgšties kiekis.

Raktažodžiai: fenoliai, flavonoidai, antocianinai, askorbo rūgštis, antioksidantai, Cornus mas L. 